\title{
Mapping the Construction Innovation System in the Russian Federation: Conceptual Model Development
}

\author{
E. Suprun ${ }^{1}$, R.A. Stewart ${ }^{1}$, O. Sahin ${ }^{1}$, K. Panuwatwanich ${ }^{1}$ \\ ${ }^{1}$ Griffith School of Engineering, Griffith University, Queensland, Australia \\ (r.stewart@griffith.edu.au)
}

\begin{abstract}
This is an ongoing research project combines System Dynamics (SD) and participatory modelling to identify variables forming the Russian Federation construction innovation system and to create an initial comprehensive conceptual model supported by stakeholderbased techniques. Quantification of this complex and dynamic construction innovation system is complicated as it includes a range of components such as information, resources, strategies, time and uncertainty. To map and conceptualize the system, system thinking and participatory techniques have been used. Methods employed academic and industry consultation and stakeholder engagement through participatory interviews. In this current paper we present the development of a conceptual model as a causal loop diagram to understand the causes, impacts and pathways leading to greater innovation performance in the Russian Federation construction industry. Moreover, the created model underpins the future development of an operationalized system dynamic model.
\end{abstract}

Keywords - Model conceptualisation, participatory modelling, system dynamics, and construction innovation

\section{INTRODUCTION}

Globally, the construction industry is often described as being a 'laggard' industry, with few exceptions. According to the previously conducted exploratory study of the authors [1], in the case of the Russian Federation this problem is even more significant, since it is a country spread across a massive territory with unique impediments to innovation diffusion. It is clear that the level of innovative activity within the construction sector needs to be improved.

Turville [2] (p. 4) points out that a country's innovation activity depends on inter-linked activities which include: industrial research; publicly funded basic research; user-driven research; knowledge transfer; institutions governing intellectual property and standards; supply of venture capital; education and training of scientists and engineers; innovation policies of government departments; science and innovation policies of RDAs; and international scientific and technological collaboration.

Innovation and innovation diffusion in the construction industry as a project-based sector should be seen in the light of the specific characteristics of a dynamic systematic context. The construction industry is closely connected to the national social structure and therefore, is highly influenced by governmental and other institutional actors. In order to improve the level of innovative activity within the construction sector, it is fundamental to identify how the interrelations among these key actors and variables of the innovation system can be combined into a complex dynamic model to create scenarios and understand policies impact. The continuously developing innovation system of the construction industry is a complex system of innovation activities highly influencing the development of construction [3]. It involves innovative milieu, different policies, interactions and a range of participating system actors such as a government, organizations, universities and research institutes.

Obviously, the linear approach to conceptualizing innovation does not offer a clear insight into the complexities of the innovation process over time. Hence, the innovation system at any context is perceived to involve mechanisms that govern the alignment of committed resources and interrelated innovation activities [4].

The herein reported, current stage of the study sought to achieve the following objectives:

- To identify the main variables of the construction innovation system and relationships between them.

- To develop a comprehensive conceptual model that utilises a causal loop diagram to link relevant innovation factors in order to better understand the behaviour of different elements that make up the Russian Federation construction innovation system.

\section{METHODOLOGY}

According to Sterman [5] (p. 85), "there is no cookbook recipe for successful system dynamics modelling, no procedure you can follow to guarantee a useful model". The modelling process, in general, is a very iterative step-by-step process. A predominant framework for system dynamics modelling in particular was developed by Sterman [5] and divided into five steps: the first two stages (i.e. Problem articulation; Formulating dynamic hypotheses) concern qualitative modelling, while the other three stages (i.e. Formulating a simulation model; Testing; Policy design and evaluation) concern computerbased modelling for quantitative simulation.

This present study completes activities to Step 2 of the modelling process [4]. Construction of the model is supported by a complete understanding of the system. A causal loop diagram (CLD) is a tool for mapping a set of relationships forming the complex system. It provides a 
more visual understanding of the existing systematic relationships between the system's components. The CLD consists of both quantitative (measurable) and qualitative (non-measurable) variables.

The innovation system in the construction industry is a complex topic requiring the use of a systemic approach. This modelling approach will assist understanding of important feedback mechanisms that characterise the dynamic behaviour of complex systems.

It is not enough for researchers to build and run computer models of complex systems using only desktop studies in order to support issues concerning innovation problems [4]. Incorporating stakeholder input in such models is essential to ensure that they facilitate effective decision making over the short-, medium- and long-term. Participatory modelling often includes involving public representatives and decision makers into an analytic modelling process [6].

As mentioned previously, many factors are involved in complex innovation systems. The list of the system's components identified through literature review and the previously conducted study must be approved by experts and stakeholders; this opinion ensures that all relevant elements are included and redundant variables removed. This process was completed through consultation with industry and academic professionals.

The selected interviewees had diverse roles, including managers, designers and researchers. As a result of consultation with the interviewees, a total of 30 of the 80 factors were retained based on their importance (Table 1). The interactions between these 30 factors were considered as described later.

Further stakeholder engagement was conducted through facilitated interviews where interactions between variables were established. Steps were then undertaken to:

i. Identify relevant stakeholders (e.g. representatives from construction and related industries, the public sector, universities and the research community);

ii. Contact nominated stakeholders and invite them to interviews; and

iii. Conduct opinion survey on the construction innovation system and discuss the key problems related to innovation in the industry.

Unstructured and highly interactive interviews were conducted with experts who have played a role in managing the innovation implementation and diffusion process in construction and the innovation policy field in Russia.

These interviewees included researchers and academic staff, private and public construction companies' employees and contractors, design consultants (i.e. design engineers), building product manufacturers, and public authorities' representatives.
TABLE I

LIST OF VARIABLES

\begin{tabular}{|c|c|c|}
\hline Variable & Brief description & References \\
\hline Level of innovation & $\begin{array}{l}\text { One of the main characteristics } \\
\text { of every industry development }\end{array}$ & {$[3,7]$} \\
\hline $\begin{array}{l}\text { Quality of } \\
\text { construction } \\
\text { projects }\end{array}$ & $\begin{array}{l}\text { Productivity and quality of } \\
\text { construction projects (final } \\
\text { product or service) }\end{array}$ & {$[7,8]$} \\
\hline Final product cost & $\begin{array}{l}\text { Final cost of a construction } \\
\text { product or service }\end{array}$ & {$[8,9]$} \\
\hline Client's satisfaction & $\begin{array}{l}\text { Satisfaction with final product } \\
\text { quality }\end{array}$ & [9] \\
\hline Profit maximization & $\begin{array}{l}\text { Maximize profitability and } \\
\text { maximize cost effectiveness }\end{array}$ & {$[1,9]$} \\
\hline $\begin{array}{l}\text { Level of public } \\
\text { R\&D activity }\end{array}$ & $\begin{array}{l}\text { Public policies promoting } \\
\text { science and R\&D }\end{array}$ & {$[8-10]$} \\
\hline $\begin{array}{l}\text { Level of private } \\
\text { R\&D activity }\end{array}$ & $\begin{array}{l}\text { Private } \\
\text { activities }\end{array}$ & {$[8-10]$} \\
\hline $\begin{array}{l}\text { R\&D expenditure } \\
\text { (public) }\end{array}$ & $\begin{array}{l}\text { Funds a government spends at } \\
\text { universities and research }\end{array}$ & [9-11] \\
\hline $\begin{array}{l}\text { R\&D expenditure } \\
\text { (industry) }\end{array}$ & Firms investments on R\&D & [9-11] \\
\hline Client's demand & $\begin{array}{l}\text { Government and private clients } \\
\text { may affect the use of innovations }\end{array}$ & {$[1,8,9]$} \\
\hline $\begin{array}{l}\text { Level of applied } \\
\text { research }\end{array}$ & $\begin{array}{l}\text { Development of methods, } \\
\text { products, systems, techniques } \\
\text { etc. }\end{array}$ & {$[8-10]$} \\
\hline $\begin{array}{l}\text { Level of basic } \\
\text { research }\end{array}$ & $\begin{array}{l}\text { Research developing industry's } \\
\text { theoretical foundations }\end{array}$ & {$[9,10]$} \\
\hline $\begin{array}{l}\text { Government } \\
\text { regulations }\end{array}$ & $\begin{array}{l}\text { Legislation, rules, building } \\
\text { codes, certification procedure }\end{array}$ & {$[1,8]$} \\
\hline $\begin{array}{l}\text { Government } \\
\text { incentives }\end{array}$ & $\begin{array}{l}\text { Public stimulating mechanisms } \\
\text { for industry development }\end{array}$ & {$[1,9]$} \\
\hline $\begin{array}{l}\text { Level of } \\
\text { government } \\
\text { intervention }\end{array}$ & $\begin{array}{l}\text { Public support and public } \\
\text { policies }\end{array}$ & {$[1,9]$} \\
\hline PPP & $\begin{array}{l}\text { Cost sharing: Public-Private } \\
\text { Partnership }\end{array}$ & {$[1,11]$} \\
\hline $\begin{array}{l}\text { Level of tax } \\
\text { incentives }\end{array}$ & $\begin{array}{l}\text { Fiscal arrangements and tax } \\
\text { privileges }\end{array}$ & {$[1,11]$} \\
\hline UIG partnership & $\begin{array}{l}\text { Partnerships between } \\
\text { universities, research institutes, } \\
\text { government and industry }\end{array}$ & {$[3,9,11]$} \\
\hline $\begin{array}{l}\text { UI R\&D } \\
\text { collaboration }\end{array}$ & $\begin{array}{l}\text { Collaborative } R \& D \text { with greater } \\
\text { industry participation }\end{array}$ & {$[1,8,11]$} \\
\hline $\begin{array}{l}\text { Level of } \\
\text { technological } \\
\text { cooperation }\end{array}$ & $\begin{array}{l}\text { Technological cooperation with } \\
\text { related and supporting } \\
\text { industries. }\end{array}$ & {$[1,8,9]$} \\
\hline $\begin{array}{l}\text { New procurement } \\
\text { approaches }\end{array}$ & $\begin{array}{l}\text { PPPs and other concession } \\
\text { projects }\end{array}$ & {$[1,12]$} \\
\hline $\begin{array}{l}\text { Life cycle cost } \\
\text { practice }\end{array}$ & $\begin{array}{l}\text { Assessment of construction } \\
\text { project over its life-cycle }\end{array}$ & [11] \\
\hline $\begin{array}{l}\text { Awareness and } \\
\text { training }\end{array}$ & $\begin{array}{l}\text { Access to the best available } \\
\text { information on innovation }\end{array}$ & {$[1,9]$} \\
\hline $\begin{array}{l}\text { Level of IPR } \\
\text { protection }\end{array}$ & $\begin{array}{l}\text { It supports efficient flows of } \\
\text { knowledge }\end{array}$ & {$[1,9]$} \\
\hline $\begin{array}{l}\text { Level of innovation } \\
\text { commercialization }\end{array}$ & $\begin{array}{l}\text { Knowledge produced through } \\
\text { R\&D transforming into products } \\
\text { with commercial value }\end{array}$ & [11] \\
\hline $\begin{array}{l}\text { Quality of higher } \\
\text { education }\end{array}$ & $\begin{array}{l}\text { Support the development of } \\
\text { educational programs }\end{array}$ & {$[1]$} \\
\hline Venture funding & $\begin{array}{l}\text { Investment funds in start- } \\
\text { ups and SMEs }\end{array}$ & $\begin{array}{l}\text { From } \\
\text { interviews }\end{array}$ \\
\hline Import substitution & $\begin{array}{l}\text { Import substitution is Russia's } \\
\text { response to imposed sanctions }\end{array}$ & $\begin{array}{l}\text { From } \\
\text { interviews }\end{array}$ \\
\hline "Brain drain" & $\begin{array}{l}\text { Increasing due to lack of support } \\
\text { and incentives for innovation }\end{array}$ & $\begin{array}{l}\text { From } \\
\text { interviews }\end{array}$ \\
\hline $\begin{array}{l}\text { Level of } \\
\text { administrative } \\
\text { barriers to } \\
\text { innovation }\end{array}$ & $\begin{array}{l}\text { The variety of building codes } \\
\text { and standards; low levels of } \\
\text { government support for industry } \\
\text { development }\end{array}$ & $\begin{array}{l}\text { From } \\
\text { interviews }\end{array}$ \\
\hline
\end{tabular}




\section{CONCEPTUAL MODEL DEVELOPMENT}

After the key variables were identified, the respondents were also asked to rank the intensity of influence and dependency between variables. Fig. 1 details the variables positions given their dependence and influence level rank. Every factor was classified into Influential, Relay, Dependent and Autonomous variables, as described below:

- Influential variables represent input variables that exert some influence on other elements, but are not dependent from the others. They must have a priority when considering strategic scenarios.

- Relay variables are also important as they are both influence the system and are dependent from influential variables.

- Dependent variables represent system's output variables that are the most impacted by other variables and the system.

- Autonomous variables are neither influential nor dependent and do not significantly affect the system.

A modeler along with stakeholders develop a CLD After asking the question: "Which impact of variable A on variable B can be observed at present?" the next step is to identify the most important relationships that allow logical construction of the associated causal loop diagram.

It also should be taken into account that some variables do not have direct connection with each other but influence can occur through other variables. Additionally, a modeler can enhance other meaningful interrelations between dynamic variables through taking into account the experts opinions during data collection, previous desktop study as well as applying the tacit knowledge of researchers analyzing the system.

The process of model construction is always subjective. However, interactions of variables are supported by experts that provide a high degree of reliability. As a result, the generated qualitative model (Fig. 2) was built using a rigorous and comprehensive analysis of the different factors involved. The finalized causal loop diagram reveals the systemic relationships and provides a broad vision of interactive factors that are part of the complex construction innovation system.

The factors used in a CLD are both quantitative (measurable) or qualitative (non-measurable). Obviously, non-measurable elements, such as Client's satisfaction, Government regulations and Quality of construction projects are not generally measured directly; however, their inclusion adds considerable realism and power to the model. In a CLD, the elements are linked together by arrows that indicate a causal relationship as a direct influence. A causal link between two variables implies direction of change between the cause and effect pairs. The polarity is "+" when two elements increase or decrease together and the polarity is ".-" when one variable increases whereas the other decreases, and vice versa.

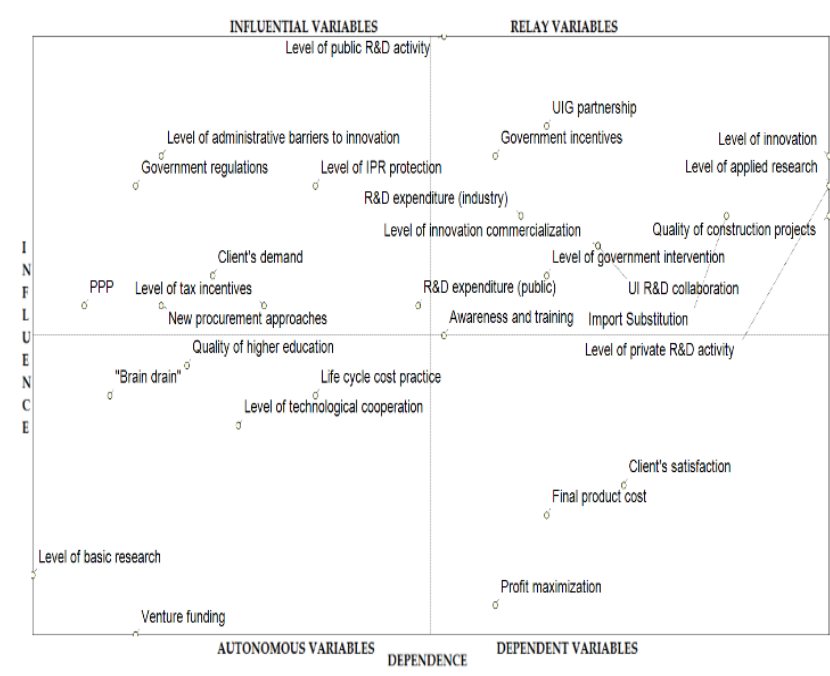

Fig. 1. Four groups of variables

\section{DISCUSSION AND CONCLUSION}

The first stage of the research consisted of the identification of essential system's factors undertaken through an expert consultation with industry and academic representatives in order to validate the list of variables. The following stage employed stakeholder engagement using the Systems Thinking technique to determine the causeand-effect relationships between different variables within the system. This stage systematically assists the modelling of complex innovation system through creating an initial CLD integrating both qualitative and quantitative variables. The contribution of experts representing three groups of innovation system's actors was undoubtedly useful due to the knowledge they have of the situation and problem addressed.

Based on the information derived from the variables dependence and influence level ranking, eight influential variables were revealed having a priority when considering strategic actions or scenarios for the industry development. They included level of administrative barriers to innovation, government regulations, and PPP. It has been found that the key influential and dependent variables are the level of public and private R\&D activity, import substitution, and government incentives. Identification and classification of key variables was essential for developing a framework suited for the Russia's construction innovation system, whereas the CLD revealed potential strategic pathways to overcome innovation diffusion challenges in the construction sector.

The conducted research is part of an ongoing project with three further research stages to be completed. The CLD explains interactions and interrelations. However, it may be considered as a didactic tool in order to understand the complexity of the system because the changes over time cannot be seen. Hence, this constructed CLD provides a roadmap for reference and is the basis for refinement and further building of a simulation model using the System Dynamics technique. 


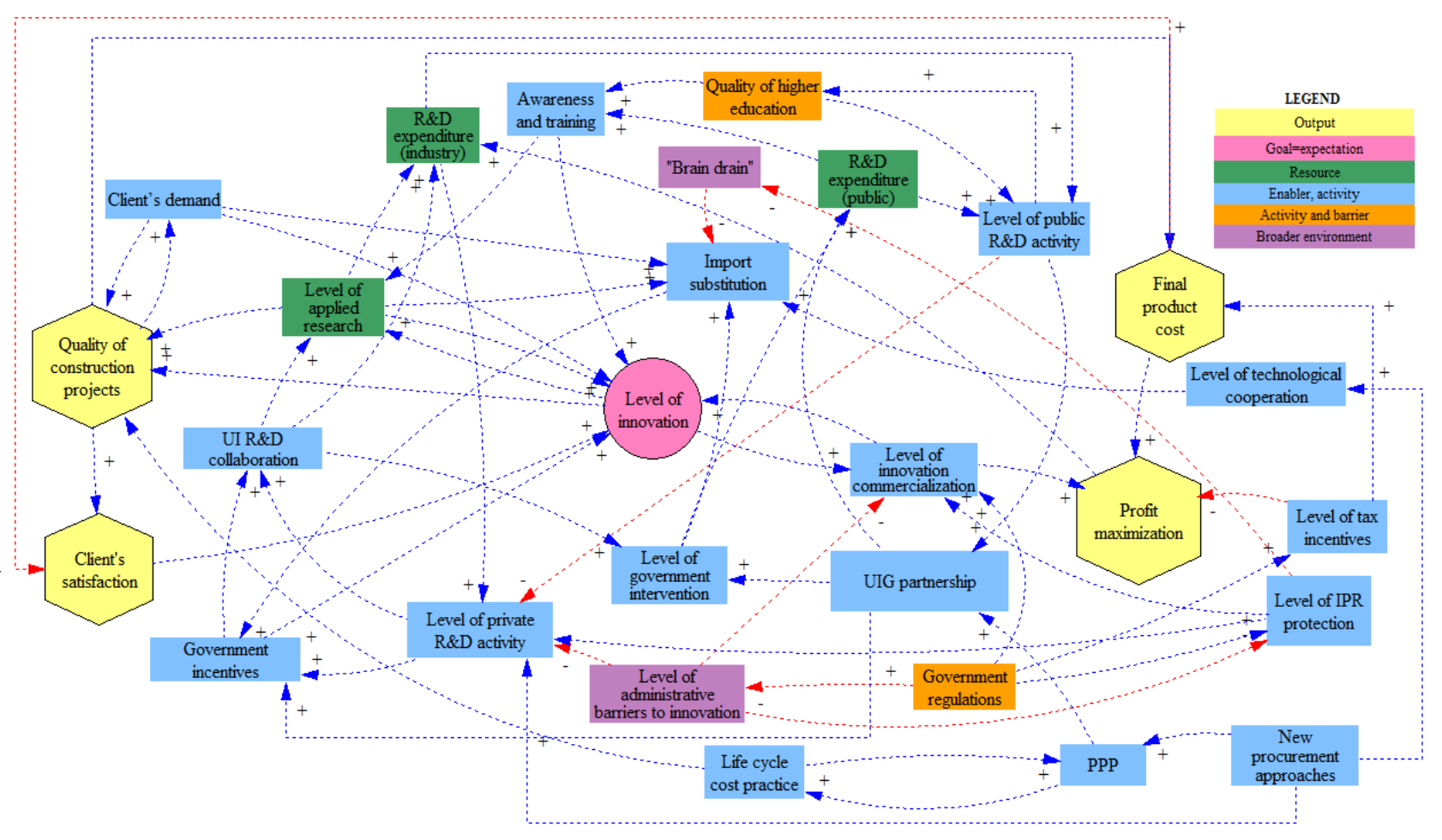

Fig. 2. Comprehensive conceptual model of construction innovation in the Russian Federation

Once the stock and flow model is developed it can be simulated by populating it with data. Available quantitative data will be collected. Nevertheless, the innovation system is very complex and consists of many relationships that are too qualitative to be expressed trustworthily by a mathematical formula. Hence, the next round of data collection will employ a participatory modelling approach in the form of workshops. Stakeholders from all three groups of the innovation system actors will discuss the outcomes of the present research analysis and focus on portraying system structure. It is especially relevant in the case of the Russian construction industry where high uncertainty and lack of data is involved. Finally, different scenarios related to construction industry development innovation diffusion, as well as the impact of a range of strategic practices and policies will be examined in rigorous manner.

\section{REFERENCES}

[1] E. V. Suprun, and R. A. Stewart, "Construction innovation diffusion in the Russian Federation: Barriers, drivers and coping strategies", Construction Innovation, vol. 15, no. 3, pp. $278-312,2015$.

[2] L. S. Turville, The Race to the Top. HM Treasury: London, 2007.

[3] N. Andersson, and K. Widén, "Construction innovation systems - a sector approach", in Proceeding of the Conference in Advancing Facilities management and Construction Through Innovation, Helsinki, Finland, pp. 203-213, January, 2005.

[4] E. Suprun, O. Sahin, R. Stewart, and K. Panuwatwanich, "Model of the Russian Federation construction innovation system: An integrated participatory systems approach", Systems (accepted August 2016).

[5] J. Sterman, Business Dynamics: Systems Thinking and Modelling for a Complex World. MA: McGraw-Hill: Boston, 2000.

[6] O. Sahin, R. A. Stewart, and M. G. Porter, "Water security through scarcity pricing and reverse osmosis: a system

dynamics approach", Journal of cleaner production, vol. 88, pp. 160-171, 2015.

[7] D. M. Gann, and A. Salter, "Innovation in project-based, service-enhanced firms: the construction of complex products and systems", Research Policy, vol. 29, pp. 955$972,2000$.

[8] X. Xue, R. Zhang, and J. Dai, "Innovation in construction: a critical review and future research", International Journal of Innovation Science, vol. 6, pp. 111-126, 2014.

[9] L. Na, G. Ofori, and M. Park, "Stimulating construction innovation in Singapore through the National System of Innovation", Journal of Construction Engineering and Management, vol. 132, pp. 1063-1082, 2006.

[10] K. D. Hampson, J.A. Kraatz, and A.X. Sanchez, $R \& D$ Investment and Impact in the Global Construction Industry. Routledge: Oxon, 2014.

[11] G. Seaden, and A. Manseau, "Public policy and construction innovation", Building Research \& Information, vol. 29, pp. 182-196, 2001.

[12] R. Leiringer, "Technological innovation in the context of PPPs: incentives, opportunities and actions", Construction Management and Economics, vol. 24, pp. 301-308, 2006. 